the Congress of Scientific Societies held in France in 1884, and again at the Paris Congress held in 1887 to inaugurate the Astrographic Chart of the heavens. Through him the Vatican Observatory was chosen as one of the eighteen observatories to take photographs for the preparation of the Chart, and in 1890 he was appointed as its director. $\mathrm{He}$ died at the Vatican on December 14, 1894, at the age of sixty years. He had been elected an honorary member of the Royal Meteorological Society in 1870, and at the time of his death was president of the Accademia dei Nuova Lincei.

\section{Prof. Ernst Küster}

Prof. Ernst Küster, who has been for thirty-one years editor of the Zeitschrift für Wissenschaftliche Mikroskopie, has been elected to honorary fellowship of the Royal Microscopical Society. Prof. Küster is professor of botany in the University, and director of the Botanical Institute and Gardens, Giessen. He was previously assistant in the Botanical Institutes at Munich and at Halle, professor of botany in the University of Kiel, and later in the University of Bonn. He is the author of "Pathologische Pflanzenanatomie" (3rd Ed., Jena, 1925), "Anleitung zur Kultur der Mikroorganismen" (3rd Ed., Leipzig, 1921), "Ueber Zonenbildung in kolloidalen Medien" (2nd Ed., Jena, 1931), and other botanical treatises, and of numerous scientific papers.

\section{Economics of Nutrition}

In the report of the Committee on Nutrition of the British Medical Association published last winter, the daily requirement of food was assessed at 3,400 Calories, and it was recommended that it should contain $50 \mathrm{gm}$. of animal or first class protein. These figures differed from those of the Committee of the Ministry of Health, which were 3,000 Calories and 37 $\mathrm{gm}$. of animal protein. A controversy arose as to which set of data was correct. A conference of representatives of the two committees has since met and published a joint report (London : H.M. Stationery Office. $2 d$. net). The Ministry's Committee gave 3,000 Calories as a guide for the energy value for large communities and institutions. The figure of 3,400 Calories of the British Medical Association Committee was meant to apply to families with children with the man performing a moderate amount of muscular work, and to be subject to an allowance of 10 per cent for waste. As was stated in an article discussing the position in Nature of January 13, p. 53, there is no real difference between the figures. The joint committee points out that no hard and fast line can be taken for differences in age and differences in work, and it gives a scale of Calories for different people. It is agreed that $80-100 \mathrm{gm}$. of total protein suffices for the daily need, the precise amount depending upon physique, occupation, habits, taste and climate. As regards the amount of animal protein, it is pointed out that there has never been any exact determination of the desirable proportion of animal to vegetable protein, and that $37 \mathrm{gm}$. is the lowest value obtained from statistics ; $50 \mathrm{gm}$. is recognised as a good value for families with growing children, who need relatively more animal protein than adults.

\section{Helium and Other Rare Gases}

IN the second Research and Development Lecture delivered under the auspices of the British Science Guild at the Royal Institution on May 30, Lord Rutherford said that there is no more interesting story in the history of science than the sequence of events, towards the close of the last century, which led to the discovery and isolation of a new group of rare gases existing in the atmosphere by Lord Rayleigh and Sir William Ramsay. The discovery that argon is present in the air in about one per cent by volume was rapidly followed by the discovery of a whole new group of inert gases, namely helium, neon, krypton and xemon. Neon is present in the air in only about one part in 100,000 by volume, and helium, krypton and xenon are present in still smaller quantities. In the early stages, these gases could only be separated in small quantities after much expense and trouble, and in a sense were regarded as scientific curiosities. The subsequent development of large liquid air plants for the separa. tion of pure oxygen from the atmosphere, in which many thousands of tons of air are liquefied annually, made possible arrangements for the separation of argon and neon in considerable quantities. On account of their characteristic properties, some of these gases have been found exceedingly useful to industry. For example, more than 30,000 cubic metres of argon are used annually in Europe in the production of the highly efficient gas-filled electric lamps. In all, about 45 million of these lamps are made each year, requiring the separation of argon from more than 5,000 tons of air. The ease with which an electric discharge passes through neon, and its characteristic luminosity, have led to a great development in the use of this rare gas for the illuminated signs with which we are so familiar in our cities to-day.

IN some respects, however, the history of the use of helium is still more striking. The presence of this gas was first detected in the sun by Sir Norman Lockyer in 1868, and for this reason he named it 'helium'. The presence of helium on the earth was first observed by Ramsay in 1895 in the gases released from old radioactive minerals. In the course of the next ten years, a few cubic metres of helium were laboriously extracted from radioactive minerals. During the War, the Board of Invention and Research of the Admiralty recognised that it would be much safer if observation balloons and dirigibles could be filled with a light, non-inflammable gas like helium rather than with hydrogen, for there is only eight per cent difference in their respective lifting powers. At the suggestion of the Board, Prof. J. C. McLennan, of the University of Toronto, made a systematic examination of the helium resources of the Empire. It was found that large supplies of helium were available in the natural gas fields of southern Alberta, 
and arrangements were made on a semi-commercial scale to purify the helium by liquefying the methane and other gases present. About the same time, the Bureau of Mines of the United States began similar experiments, using the natural gases of Texas, which are rich in helium. At the end of the War, millions of cubic feet of helium were separated by liquefaction methods, and the cost was found to be sufficiently low to use it in airships in place of hydrogen. The U.S. airships, the Shenandoah and the Akron, were both filled with helium to avoid the dangers of fire. Apart from this and other industrial uses, helium is of great importance in the liquid form for attaining temperatures not far removed from absolute zero. A number of cryogenic laboratories employing liquid helium are in active operation in Europe, Canada and the United States, for the study of the properties of matter near the absolute zero of temperatures.

\section{Congress of Anthropological and Ethnological Sciences}

A PReliminary programme of the first session of the International Congress of Anthropological and Ethnological Sciences to meet in London under the presidency of the Earl of Onslow from July 30 until August 4 next is now available. The headquarters will be at University College, Gower Street, W.C.2. The inaugural meeting will take place in the Great Hall of the College on July 30 at 3 p.m., when H.R.H. the Duke of York will receive the delegates and declare the Congress open, and Lord Onslow will deliver his presidential address. On the same day at 10 p.m. H.M. Government will hold a reception of the members of the Congress at Lancaster House, St. James's, S.W. The business of the Congress will be conducted in general and sectional meetings. At the first of the general meetings, which will be held on July 31 at 8.30 p.m., Sir Aurel Stein will deliver the Huxley Memorial Lecture of the Royal Anthropological Institute and will receive the Institute's Huxley Memorial Medal for 1934. At subsequent general meetings in the evenings of the following days, the Congress will be addressed by Dr. R. R. Marett, Prof. T. C. Hodson, and Prof. J. B. S. Haldane, each of whom will deal with some one aspect of present tendencies in anthropological studies. Communications addressed to the Congress by its members will be submitted to meetings of the sections, of which there will be eight, each one dealing with a major division of the studies with which the Congress is concerned.

So far as it is possible to judge from this preliminary outline, the proceedings of the sections will be of the greatest interest. In each section topics of inquiry are suggested, although members are not thereby necessarily precluded from submitting communications on other matters. In the Anatomical and Physical Section, which will meet under Prof. Elliot Smith, for example, the central theme will be man's place among the primates. In most sections, however, the range is sufficiently wide to cover all points which members are likely to have time or desire to discuss. Joint meetings between two or more sections occupy a prominent place in the programme. The Section of Ethnography, which, naturally, is expected to have the heaviest list of communications, will meet in three divisions, General Ethnography under Dr. A. C. Haddon, African Ethnography under the Rev. E. W. Smith and American Ethnography under Capt. T. A. Joyce. The last named sub-section has been specially arranged with the view of welcoming American workers on their way to attend the International Congress of Americanists to be held later at Seville. It will take as its central theme of discussion the interrelation of pre-Spanish American culture centres and their possible connexion with extra-American influences, affording, it is hoped, a welcome opportunity for placing on record the results of the most recent developments in research. In the African Section current problems impinging on questions of administration and the future development of the African will be kept well in view. The subscription to the Congress is: members $£ 1$, associates $10 \mathrm{~s}$. Further particulars may be obtained from the Congress Secretaries, c/o the Royal Anthropological Institute, 52 Upper Bedford Place, London, W.C.2.

\section{Japanese Trade Competition}

JAPANESE competition in the world's markets is more than a new and noteworthy fact. Discussing the matter in a recent issue of the Industrial Chemist, Sir Harry McGowan, chairman and managing director of Imperial Chemical Industries, Ltd., shows that by no means the whole story involves the long hours of work and the low standard of living of the Japanese worker; contributory aids to Japan's advance are her realisation that, in times of depression, price is more important than quality, and her study of the needs of individual markets. "Her manufacturers . . . give each customer what he wants at the time and place that it is wanted, and patterned, designed, and packed in a manner to please his particular fancy.... They quote in his own language, and express units of quantity and price in the measurements of his country." Japan needs to sell goods abroad to maintain some equilibrium in her trade balance, to support her rapidly growing population, and to pay for her increasing armaments. She has the advantage of a considerably depreciated currency; a newcomer into the industrial arena, she has bought the most up-to-date machinery and adopted the most suitable methods, and she has organised her industries in large-scale units. She has evolved a system of industrial and governmental co-operation in the conduct of export campaigns. Sir Harry McGowan counsels us to take prompt and vigorous steps to put ourselves so far as possible on a competitive basis. We will not, and indeed cannot, depress the standard of living of our workpeople, but we can reap the advantages of industrial organisation and the effective planning of export trade. The time has come for closer personal contact between British and Japanese industrialists, and for discussion which will lead to a tempering of healthy competition with reasonable co-operation. 